\title{
Література:
}

1. Єрмоленко С. Я. Синтаксис і стилістична семантика. Київ: Наукова думка, 1982. 264 с.

2. Жиленко І. В. Свангеліє від ластівки: Вибрані твори. Київ: Унів. вид-во «Пульсари», 2006. 488 с.

3. Шульжук К. Ф. Синтаксис української мови: Підручник. Київ: Видавничий центр «Академія», 2004. 406 с.

DOI https://doi.org/10.30525/978-9934-26-073-5-1-2

\section{УКРАЇНСЬКІ ПАРЕМІЇ З СОМАТИЧНИМ КОМПОНЕНТОМ ЯК РЕПРЕЗЕНТАНТИ СОМАТИЧНОГО КУЛЬТУРНОГО КОДУ}

\author{
Ворона Н. О. \\ викладач кафедри мовної підготовки іноземних громадян \\ Сумського державного університету \\ Пилипенко-Фріцак Н. А. \\ викладач кафедри мовної підготовки іноземних громадян \\ Сумського державного університету \\ м. Суми, Украӥна
}

Сучасне мовознавство характеризується розширенням кола об'єктів вивчення та зміною поглядів на традиційні об'єкти лінгвістики. Усе більше уваги приділяється принципу антропоцентризму як прояву людського фактора у мові, що ставить за мету вивчення взаємодії мови і людини [7]. Дослідження мовних одиніць у контексті антропоцентризму проводиться з позицій мовної особистості, у свідомості якої укладена сукупність найрізноманітніших знань i уявлень про навколишню дійсність, яка утворює мовну картину світу, властиву національній культурі. Зважаючи на те, що фразеологічні одиниці відображають моменти дійсності, пов'язані 3 існуванням та діяльністю людини, $є$ національно специфічними елементами, джерелом відомостей про культуру, відбивають уявлення народу про норму, мораль, звички тощо, відображають своєрідність національної культури, відбивають світосприйняття народу через мову, вони (фразеологічні одиниці) являють собою цінний матеріал для кращого розуміння антропоцентричної за своєю природою мовної світової моделі. Серед 
широкого розмаїття фразеологічних одиниць особливої уваги, на нашу думку, заслуговують паремії з соматизмами.

Метою запропонованого дослідження є аналіз специфіки вживання паремій із соматизмами як репрезентантів соматичного культурного коду українського народу, оскільки тіло людини сприймається як зразок, на основі якого будується система координат традиційної культури (простір, час, моральні константи, ціннісні координати тощо). Паремії 3 соматизмами набувають поширення серед сучасних лінгвістичних досліджень [2, с. 114-115], оскільки розуміння навколишнього світу почалося з усвідомлення та пізнання людиною себе, зокрема і з пізнання власного тіла.

Антропоцентричні фразеологізми категоризують навколишній світ і внутрішній світ людини через коди культури, за допомогою яких відбувається опис матеріального і духовного світу носіїв певної мови [6]. На думку В.В.Красних, культурний код може бути визначений як «"сітка", яку культура "накидає" на навколишній світ, членує, категоризує, структурує і оцінює його» [3, с. 5]; набір національнодетермінованих і пов'язаних між собою образів і уявлень, що формують національну картину світу окремого народу займають центральне місце в національному культурному просторі [4, с. 27]; формують систему координат, котра містить і відтворює еталони культури [1]. Більшість дослідників виділяють наступні коди культури: соматический (тілесний); просторовий; часовий; предметний; біоморфний; духовний.

Особливої уваги заслуговує соматичний культурний код як один із найдавніший і таких, що є універсальним засобом вираження антропоцентричності картини світу. Через усвідомлення себе людина приходить до опису навколишнього світу, екстраполюючи знання про себе самого на навколишню дійсність [5, с. 198]. Прагнучи усвідомити себе як частину всього сущого, давні люди у той же час намагаються відокремити себе від него. Осмислюючи реальність, людина знов і знов повертається до опису самої себе, накладаючи на світ знання про себе $\mathrm{i}$ навпаки. Люди осягали навколишній світ за допомогою органів чуття i вимірювали та відображали навколишній простір за допомогою частин тіла (ніг, рук, голови тощо).

Більшість лінгвістів, з роботами яких ми ознайомились, на перше місце у соматичних пареміях ставить компонент «голова» як найбільш поширений и важливий. Соматизм «голова» у пареміях - це насамперед втілення людського розуму, інтелектуально розвинена людина. На противагу цьому «відсутність» голови або якісь ії дефекти - ознака глупоти i неадекватності. До першої групи премій можна віднести 
зокрема такі: скільки голів, стільки й умів; на те й голова, щуоб у ній розум був; розум в голові-самочвіти серед каміння; одна розумна голова рятує тисячу; не силою мисливещь подолає лева, а тим, що мисливська мудра голова. Оскільки паремії містять закінчену думку, вони є невичерпним джерелом інформації щодо цінностей, моралі, традицій носіїв мови. 3 наведених прикладів видно, що для українців інтелектуальні здібності дуже важливі, розум цінується вище за матеріальні блага: ліпше порожня кишеня, ніж голова; що ті гроші, коли немає нічого в голові? Розум цінується і більше за красу: хвалилася опенька, щуо на ній шапочка гарненька, а гриб ій: «Гарненька, та дарма - під нею голови нема»; хоч не з красою, аби з головою. У нерозумних і неадекватних людей «цвілі голови», «немає клепки в голові», голова «соломою набита», в ній «немає нічого», «курячий розум», «горобиі свищуть», «сім літ не метено», так порожньо, що «хоч село в голову вклади». Паремії з соматизмом «голова» можуть розповісти і про характер людини, зокрема про людські вади: вередливому «хоч голову пробии, то не вгодиш», він «жує голову», «щчо Божий день, усе голову їсть», впертому «хоч кілка на голові теши», жадібні «ані каменя не дадуть $i$ голову провалити», у лицемірних «ангельське волосся, а чортова голова», у невмілих «хвіст перед веде, а голова ззаду йде», пихатий «дере голову, як попова кобила», «через голови плює», у ледачого «у суботу на роботу голова боліла, а в неділю на музики мало не злетіла». Соматизм голова може вживатися і у значенні чогось чи когось головного або дуже важливого: «хліб - усьому голова», «здоров'я - усьому голова», в родині «чоловік - усьому голова», «чоловік-голова, а жінка - серче», «чоловік-голова, ажінка-душа».

Друге місце за своєю поширеністю в українських пареміях посідає соматизм «рука», що цілком закономірно для працьовитої і працелюбної української нації з огляду на те, що рука - це насамперед орган праці, в метафоричному переосмисленні - «майстерність», «діяльність». Про працьовитість і вправність українців свідчать такі паремії: де руки $\check{u}$ охота, там скора робота; роботящі руки гори вернуть, руки малі, а до роботи вдалі. Справжні майстри, які працюють «на обидві руки», в яких «руки золоті», завжди і мали повагу в українському суспільстві, і були здатні заробити гроші для своєї родини: майстра руки прогодують, майстрова людина не вийде з хати з порожніми руками, у коваля руки чорні, а хліб білий. Невмілі і недобросовісні навпаки - викликали презирство, бо вони за роботу бралися «наче не своїми руками», у них «з рук падає все», «руки болять», «воскові руки». «Руки болять» і у ледарів, які здатні «тільки пить та гулять», у них «білі руки», що «роботи бояться», «чужі труди люблять». Паремії з елементом «рука» образно 
змальовують й інші людські недоліки, зокрема жадібність: в багача очі завидющі, а руки загребущі; скупий «дає $i$ з рук не випускає», у нього «рука до себе крива»; злому «не клади в рот руки, бо відкусить»; заздрісному «у чужій руичі завжди шмат більший»; у злодія - «довгі руки», «рука свебить до того, щзо погано лежсть», у хвалька - «язик діє, а рука не вміє». «Рука», так само як і «голова», мислиться носіями української мови як щось надважливе, без чого нормальне життя просто неможливе, тому близьку людину, гарного друга, вправного помічника називають «права рука», говорять, що без нього, «як без рук». «Руки» це також елемент контролю, зокрема у вихованні: дитину серием люби, а в руках держи.

Соматизм «нога» у пареміях виступає переважно уособленням опори i pуху, як у буквальному сенсі, коли, наприклад, про швидкий рух говорять: ти біжи мені бігом, щуоб одна нога - тут, а друга - там, так і в більш метафоричному значені, коли йдеться про життєвий шлях: життя - як стерня, не пройдеш, ноги не вколовши. Якщо у людини в житті все добре і стабільно, можна сказати, що вона «добре стоїть на ногах», але так буває не завжди: кінь на чотирьох ногах, та ц̆ спотикається, а людина на двох, та й щоб не спіткнулася? Так само через соматичні паремії з компонентом «нога» передається і поширена у пареміях тематика людських недоліків, зокрема брехуни усе перевертають «догори ногами», ледарі «думкою - в небі, ногами - в постелі», лицемір - «в ноги кланяється, а за п'яти кусає», хитрий «i риби наловить, $і$ ноги не замочить», невмілий «оце вщив: два чоботи на одну ногу», а «дурного на ноги тручай, а він все одно на голову впаде».

Отже, паремії 3 соматичним компонентом являють собою невід'ємну частину мовної картини світу кожного етносу, є найціннішим джерелом відомостей про культуру, репрезентантами стереотипів народної свідомості у межах культурного коду, зокрема соматичного. Вважаємо, що проблематика соматичних паремій через антропоцентричну складову, через універсальність, високу частотність уживання в різноманітних мовних ситуаціях має перспективи подальшого дослідження.

\section{Література:}

1. Бацевич Ф. С. Словник термінів міжкультурної комунікації. URL : http://terminy-mizhkult-komunikacii.wikidot.com/slovnyk (дата звернення 05.04.2021). 
2. Ворона Н. О., Пилипенко-Фріцак Н. А. Українські паремії 3 соматичними компонентами. Вісник Маріупольського державного університету. Філологія. Маріуполь, 2020. Вип. 22. С. 113-121.

3. Красных В.В. Коды и эталоны культуры (приглашение к разговору). Язык, сознание, коммуникация: сб. статей / отв. ред. В. В. Красных, А. И. Изотов. Москва, 2001. Вып. 19. С. 5-19.

4. Маслова В. А., Пименова М. В. Коды лингвокультуры. Москва : Флинта, 2016. 180 c.

5. Шарманова Н. М. Коди культури та їх репрезентація в усталених словесних комплексах. Філологічні студї. Науковий вісник Криворізького державного педагогічного університету. Кривий Ріг, 2013. Вип. 9(2). С. 194-204.

6. Alexander A. Shestakov. Cultural code concept in contemporary world. Department of Public Administration and Organizational Theory Bergen University. Spring - 2008. 103 p.

7. Valentine S. Lee, Ainakul B. Tumanova and Zhanat H. Salkhanova. New Approaches to a Subject of Anthropocentric Linguistics. International journal of environmental \& Science education. 2016. Vol. 11, No. 11. P. 4716-4728.

DOI https://doi.org/10.30525/978-9934-26-073-5-1-3

\title{
СЛОВОТВОРЧІ Й ФОРМОТВОРЧІ ЧАСТКИ В ДРАМІ ЛЕСІ УКРАЇНКИ «РУФІН І ПРІСЦІЛЛА»
}

\author{
Гандзюк О. М. \\ кандидат філологічних наук, \\ доиент кафедри української мови \\ Волинського національного університету імені Лесі Українки \\ м. Луцььк, Украӥна
}

Частка - «це службова частина мови, яка надає слову чи реченню додаткового відтінку або слугує засобом творення слів та похідних слів». За роллю у слові та реченні частки поділяються на 1) формотворчі, 2) словотворчі, 3) фразові (заперечні та модальні) [1, с. 311].

У названій драмі Лесі Українки широко вжиті словотворчі й формотворчі частки. Аналіз цих типів часток здійснюємо на матеріалі твору «Руфін і Прісцілла», опублікованому в другому томі драматичних творів в двох томах (К.: Наукова думка, 1987.726 с.). 